\title{
The effects of combined administration of human umbilical cord-derived multipotent mesenchymal stromal cells and melatonin or fibroblast growth factor-2 to aged mice with a toxic cuprizone model of demyelination
}

\author{
Labunets I. ${ }^{1}$, Utko N. ${ }^{1}$, Toporova O. ${ }^{1,2}$, Pokholenko Ia. ${ }^{1,2}$, Panteleymonova T. ${ }^{1}$, Litoshenko Z. ${ }^{1}$, Butenko G. ${ }^{1}$ \\ ${ }^{1}$ State Institute of Genetic and Regenerative Medicine of the National Academy of Medical Sciences of Ukraine, Kyiv, Ukraine \\ ${ }^{2}$ Institute of Molecular Biology and Genetics of the National Academy of Sciences of Ukraine, Kyiv, Ukraine \\ Corresponding author’s e-mail: irina_labunets@ukr.net
}

\section{ABSTRACT}

The effect of transplantation of umbilical cord-derived multipotent mesenchymal stromal cells (UC-MMSCs) to patients with demyelinating diseases depends on the age of the recipient and can change under the influence of hormones or growth factors.

PURPOSE. To investigate the effect of exogenous melatonin and recombinant human fibroblast growth factor-2 (rhFGF-2) on the effects of UC-MMSCs transplanted into aged mice with an experimental model of multiple sclerosis.

MATERIAL AND METHODS. 129/Sv mice, 15-17 months old, received the neurotoxin cuprizone with food for 3 weeks. From the $10^{\text {th }}$ day of the cuprizone diet, $5 \cdot 10^{5} \mathrm{UC}-\mathrm{MMSC}$ were injected intravenously. From the $11^{\text {th }}$ day they received melatonin at $6^{00}$ p.m. or rhFGF-2. The behavioral parameters were evaluated in the open field test and rotarod test. In the brain, the activity of superoxide dismutase, catalase, glutathione peroxidase, glutathione reductase and the level of malondialdehyde (MDA) were assessed.

RESULTS. Cuprizone intake reduces the behavioral response in mice compared to the intact group. The transplantation of UC-MMSCs increases the number of rearings and muscle tone in mice. Melatonin injections enhance the effects of cells on these parameters, as well as increase the motor and emotional activity of animals. The injection of rhFGF-2 preserves the effect of cells on behavioral response and increases locomotor activity in mice. After the injection of UC-MMSCs with melatonin or rhFGF-2, the content of MDA in the brain decreases and the activity of antioxidant enzymes increases, this is more significant under the influence of melatonin.

CONCLUSION. Exogenous melatonin and rhFGF-2 improve the effects of transplanted UC-MMSCs on behavioral responses and brain antioxidant defenses in aged mice with cuprizone diet. At the same time, the positive effect of the combination of cells with melatonin is more pronounced.

KEY WORDS: umbilical cord-derived multipotent mesenchymal stromal cells; melatonin; rhFGF-2; cuprizone; demyelination; behavioral response; oxidative stress

One of the widespread disease of the central nervous system (CNS), multiple sclerosis, occurs mainly in young people, but recently it is increasingly being detected in people over 50 years old [1]. Oxidative stress and neuroinflammation are one of the pathogenetic links of functional disorders of the nervous system in this disease, which manifestations increase with age [2].
The transplantation of multipotent mesenchymal stromal cells (MMSCs) of various sources is increasingly used in treatment programs for patients with multiple sclerosis [3, 4]. In particular, human umbilical cord-derived MMSCs (UC-MMSCs) are capable of multilinear differentiation, the production of anti-inflammatory cytokines and growth factors (IL-10 and TGF- $\beta$ ), have a fairly good proliferative potential in vitro and 

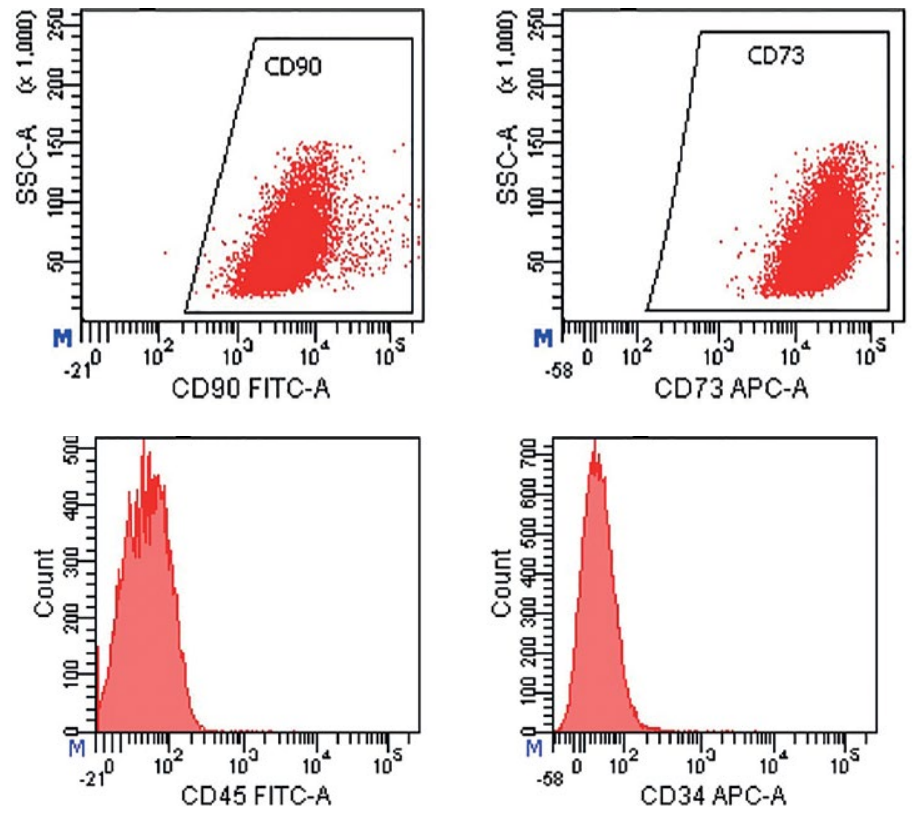

low immunogenicity [5-7]. At the same time, the effectiveness of UCMMSCs transplantation is not always evident, which may partly be due to the different ages of the recipients $[8,9]$. Thus, the authors found that the survival and the ability for migration of MMSCs obtained from bone marrow or adipose tissue of young people after their administration into an aged organism is less than in a young one. Using an experimental model of demyelinating diseases, we have also shown a less pronounced positive effect of transplanted UC-MMSCs in aged recipient mice compared to adult animals [10].

It is known that hormones and growth factors can change the biological properties of MMSCs and their therapeutic effect after transplantation into an organism with disease. Thus, the pineal hormone melatonin affects the differentiation, proliferation, migration, and survival of MMSCs $[11,12]$. In addition, this hormone regulates the biorhythms of many body functions, exhibits neurotrophic, antioxidant, anti-inflammatory, immunomodulatory and anti-apoptotic properties, thus affecting on some links in the pathogenesis of multiple sclerosis $[2,13]$. The production of melatonin by the pineal gland decreases with aging of animals and the development of demyelinating diseases, while exogenous melatonin exhibits neuroprotective and remyelinating effects in such mice [12, 14-16]

Fibroblast growth factor-2 (FGF-2, basic FGF) alters the migration, proliferation, and differentiation of MMSCs $[17,18]$. This growth factor also reduces the number of microglial cells and macrophages in the brain, changes the activity of antioxidant enzymes, and improves behavioral responses in animals with experimental models of multiple sclerosis [1922]. The production of FGF-2 in MMSCs changes under the influence of melatonin [23]. Therefore, a comparative analysis of the effects of the combination of UC-MMSCs with melatonin or FGF-2 will provide additional information on the pathways of the effect of melatonin on the MMSCs functions in demyelinating diseases in an aged organism.

PURPOSE. To investigate the effect of combined injection of UCMMSCs and melatonin or rhFGF-2 on behavioral responses, factors of oxidative stress and antioxidant protection of the brain in aged mice with an experimental model of multiple sclerosis.

\section{MATERIALS AND METHODS}

Animals. The studies were performed on male 129/Sv mice (genotype $\mathrm{H}-2^{b}$ ) 15-17 months old from the vivarium of the State Institute of Genetic and Regenerative Medicine of the NAMS of Ukraine. Mice of this strain and age are sensitive to the effects of the neurotoxin cuprizone [10]. The animals were kept under standard conditions, 12:12 light cycle with free

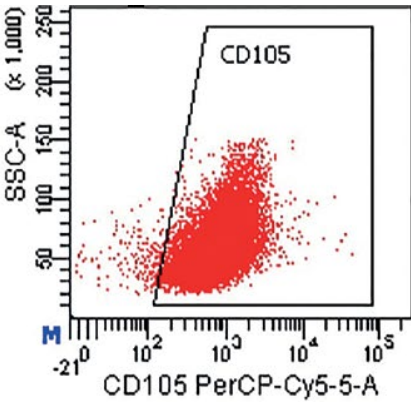

Fig. 1. Histograms of expression of CD90, CD73, CD105, CD45 and CD34 surface markers on UC-MMSCs determined by flow cytometry.

access to food and water ad libitum. To obtain tissue for analysis, mice were decapitated under ether anaesthesia in the morning. All experimental studies were carried out in accordance with the "European Convention for the Protection of Vertebrate Animals, which are used for experimental and other scientific purposes" (Strasbourg, 1986) and Article 26 of the Law of Ukraine "On the Protection of Animals from Cruelty" (№ 3447-IV, dated 21.02.2006).

Experimental models. A previously described toxic cuprizone model of demyelination was used in the study [24]. Aged mice received the neurotoxin cuprizone [bis(cyclohexanone)-oxaldihydrazone] (Sigma-Aldrich, Germany) with food daily ( $0.2 \%$ of mass of the daily feed), for three weeks. We have previously shown that in aged 129/Sv mice, administration of cuprizone according to this scheme leads not only to demyelination of neuronal axons, but also damage to the neurons in the central nervous system (CNS), as well as the development of oxidative stress and neuroinflammation in the brain [14].

Isolation and cultivation of UC-MMSCs. MMSCs were isolated from the umbilical cord of a male fetus of a healthy woman after normal delivery (26 years old, the $39^{\text {th }}$ week of physiological pregnancy). The woman signed an informed consent to provide the umbilical cord for research. The primary cell culture of the umbilical cord was obtained by explant culture method. Under sterile condition, the vessels were removed from the umbilical cord, and the tissue was minced into 2-3 mm fragments; after that it was washed in phosphate buffered saline (PBS, BioWest, France). The resulting explants were cultured in flasks for adherent cells in a DMEM/F12 nutrient medium (Biowest, France) supplemented with antibiotics (100 U/mL benzylpenicillin, $100 \mu \mathrm{g} / \mathrm{mL}$ streptomycin (Arterium, Ukraine) supplemented with $10 \%$ fetal bovine serum (HyClone, USA) at a temperature of $+37^{\circ} \mathrm{C}$ and $5 \% \mathrm{CO}_{2}[10,25]$.

UC-MMSCs of the second passage were used for the transplantation into experimental mice. Upon reaching 70-80\% confluence of the monolayer the cells were detached into suspension using a mixture of trypsin and Versene solutions (Biowest, France) 1:1. The cells were analyzed for the expression of surface markers CD90, CD73, CD105, CD34, and CD45. Immunophenotyping of cells by flow cytometry was performed using mouse anti-human fluorochrome-labeled antibodies CD90-FITC, CD73-APC, CD105-PerCP-Cy5-5, CD45-FITC, CD34-APC (BD Bioscience, USA) on a BD FACSAria cell sorter (Becton Dickinson, USA). The population of the obtained MMSCs was characterized by the immunophenotype CD73+90+105+45-34- (Fig. 1), and also showed the ability to differentiate in the multilinear direction in vitro. Adipogenic, osteogenic, and chondrogenic induction was performed according to the recommendations of the manufacturer StemPro ${ }^{\circledR}$ Differentiation Kits (Gibco, USA) [26].

To prepare for transplantation, the cells were washed twice with 10fold volumes of PBS and pelleted by centrifugation at $800 \mathrm{rpm}$ for $10 \mathrm{~min}$. The viability of UC-MMSCs before transplantation assessed by the Trypan blue staining was $96 \%$ [27].

UC-MMSCs of the $2^{\text {nd }}$ passage were injected once into the tail vein on the $10^{\text {th }}$ day of the cuprizone diet at a dose of $5 \cdot 10^{5}$ cells per $50 \mu \mathrm{L}$ in saline. It was found that after 8-10 days of cuprizone diet in the brain of mice of different lines, including 129/Sv, there was oligodendrocyte apoptosis and changes in the structure of neurons and behavior [24, 28]. In addition, the therapeutic effect of human bone marrow-derived MMSCs after transplantation into mice taking cuprizone has been shown [29]. 
Table 1. Experimental groups of animals.

BLOCK 1

Intact group (standard diet)

Mice with cuprizone diet and injections of $0.9 \%$ saline

(control group)

Mice with cuprizone diet and melatonin injections

Mice with cuprizone diet and one injection of UC-MMSCs

Mice with cuprizone diet and injections of UC-MMSCs and melatonin

Melatonin (Sigma, USA) was dissolved in saline and administered to mice intraperitoneally at the dose of $1 \mathrm{mg} / \mathrm{kg}$ at $6^{00} \mathrm{p}$.m. daily, from the $11^{\text {th }}$ to the $21^{\text {st }}$ day of the cuprizone diet.

Recombinant human fibroblast growth factor-2 (rhFGF-2) expressed in E. coli cells according to the standard procedure [21]. After the lysis of bacterial cells, the resulting protein was purified by affinity chromatography using Heparin-Sepharose to a homogeneity (not less than $98 \%$ ). The angiogenic activity of rhFGF-2 was evaluated in chick chorioallantoic membrane (CAM) assay. RhFGF-2, dissolved in saline, was administered to mice intraperitoneally at a dose of $20 \mu \mathrm{g} / \mathrm{kg}$, starting from the $11^{\text {th }}$ day of the cuprizone diet, with an interval of 48 hours, a total of 7 injections. This growth factor administration scheme has shown its effectiveness in our previous studies on adult mice with a cuprizone model of demyelination [21].

Experimental groups. Aged mice were divided into 10 groups for two blocks of experiments with cells and melatonin, as well as experiments with cells and rhFGF-2 (Table 1). Each experimental group consisted of 10 mice.
All mice on the $21^{\text {st }}$ day of cuprizone diet, as well as intact animals, simultaneously underwent behavioral tests. The next day (the $22^{\text {nd }}$ day of the experiment), all mice were decapitated and the brains were isolated for biochemical studies.

Behavioral parameters of mice were studied in the "open field" test and rotarod test [30]. In the "open field" test, we examined the horizontal locomotor activity (a number of crossed squares), the exploratory behavior (a number of rearings and explored holes), and the emotional activity (number of fecal boluses and grooming). Mice of all groups were tested for 3 minutes. The rotarod test enables to assess muscle tone, motor coordination and balance of experimental animals. Data were presented as the cumulative time (s) of mice latency on the rotarod at a rotation speed of $10 \mathrm{rpm}$ and $20 \mathrm{rpm}$.

The factors of oxidative stress and antioxidant protection of the brain. The level of malondialdehyde (MDA) in the brain of mice was measured using a $\mu$ Quant spectrophotometer (BioTek, USA) at a wavelength of $535 \mathrm{~nm}$ by the intensity of staining of the trimethine complex, which is formed between MDA and thiobarbituric acid, as described previously [10, 21].

The activity of antioxidant enzymes was measured in supernatants of brain homogenates by the spectrophotometric method on a $\mu$ Quant spectrophotometer (BioTek, USA), as we described earlier [10, 21]. Superoxide dismutase (SOD) activity was measured in conventional units according to its ability to inhibit the reaction of adrenaline autooxidation into adrenochrome at pH 10.2 per $1 \mathrm{mg}$ of protein per $1 \mathrm{~min}$; catalase activity - in micromoles of utilized $\mathrm{H}_{2} \mathrm{O}_{2}$ per $1 \mathrm{mg}$ of protein per $1 \mathrm{~min}$; activity of glutathione peroxidase (GP) and glutathione reductase (GR) - in nanomoles of oxidized NADPH per $1 \mathrm{mg}$ of protein per $1 \mathrm{~min}$. The protein content in the brain was assessed by the Lowry method. All reagents are Riedel-deHaen (Fluka, Germany).

Statistical analysis of the results was carried out using Student's t-test. The results were presented as the mean and the standard error of the mean $(\mathrm{M} \pm \mathrm{SEM})$. The difference between the indexes was considered statistically significant at $p<0.05$. Statistica 7.0 software (StatSoft Inc., USA) was used for statistical analysis of the results.

\begin{tabular}{|c|c|c|c|c|c|}
\hline \multirow[b]{2}{*}{ INDICATOR } & \multicolumn{5}{|c|}{ EXPERIMENTAL GROUPS } \\
\hline & $\begin{array}{l}\text { INTACT } \\
(\mathbf{n}=10)\end{array}$ & $\begin{array}{c}\text { CUPRIZONE + } \\
\text { SALINE } \\
\text { (CONTROL) } \\
(\mathbf{n}=10)\end{array}$ & $\begin{array}{c}\text { CUPRIZONE + } \\
\text { MELATONIN } \\
(\mathbf{n}=10)\end{array}$ & $\begin{array}{c}\text { CUPRIZONE + } \\
\text { UC-MMSCs } \\
(n=10)\end{array}$ & $\begin{array}{l}\text { CUPRIZONE + } \\
\text { UC-MMSCS+ } \\
\text { MELATONIN } \\
(n=10)\end{array}$ \\
\hline \multicolumn{6}{|l|}{ Behavioral testing } \\
\hline Number of crossings & $50.9 \pm 6.1$ & $22.5 \pm 5.1$ * & $45.2 \pm 4.1^{\#}$ & $27.7 \pm 6.8$ * & $54.5 \pm 10.1^{\# \& ~}$ \\
\hline Number of rearings & $1.4 \pm 0.3$ & $0.2 \pm 0.06$ * & $0.4 \pm 0.2$ * & $0.7 \pm 0.1 * \#$ & $1.0 \pm 0.3^{\#}$ \\
\hline Number of boluses & $1.7 \pm 0.3$ & $0.3 \pm 0.1^{*}$ & $1.2 \pm 0.3^{\#}$ & $0.1 \pm 0.05^{\star}$ & $0.1 \pm 0.05^{\star \wedge}$ \\
\hline Number of explored holes & $2.7 \pm 0.4$ & $0.8 \pm 0.2$ * & $0.6 \pm 0.2^{*}$ & $0.5 \pm 0.1^{*}$ & $0.7 \pm 0.2^{*}$ \\
\hline Number of grooming & $0.33 \pm 0.04$ & $0.33 \pm 0.1$ & $0.4 \pm 0.1$ & $0.5 \pm 0.1$ & $0.7 \pm 0.1^{\star \# \wedge}$ \\
\hline Rotarod, sec & $86.0 \pm 8.5$ & $65.2 \pm 5.7^{\star}$ & $66.2 \pm 4.2$ & $90.6 \pm 19.6$ & $191.6 \pm 24.7^{\star \# \& \wedge}$ \\
\hline \multicolumn{6}{|l|}{ Markers of oxidative stress in the brain } \\
\hline Malondialdehyde, nM/mg & $4.0 \pm 0.2$ & $4.8 \pm 0.2^{*}$ & $3.9 \pm 0.3^{\#}$ & $4.9 \pm 0.3^{* \wedge}$ & $4.2 \pm 0.1^{\# \&}$ \\
\hline Superoxide dismutase, U/mg.min & $15.2 \pm 0.3$ & $11.9 \pm 1.3^{*}$ & $12.1 \pm 1.2^{*}$ & $13.1 \pm 0.9^{*}$ & $13.6 \pm 0.5^{\star}$ \\
\hline Catalase, $\mu \mathrm{M} / \mathrm{mg} \cdot \min$ & $2.2 \pm 0.3$ & $1.1 \pm 0.1^{*}$ & $1.3 \pm 0.2$ * & $1.4 \pm 0.2^{\star}$ & $1.4 \pm 0.2^{\star}$ \\
\hline Glutathione peroxidase, $\mathrm{nM} / \mathrm{mg} \cdot \mathrm{min}$ & $5.8 \pm 0.2$ & $4.6 \pm 0.3^{*}$ & $5.5 \pm 0.2^{\#}$ & $4.3 \pm 0.5^{\star \wedge}$ & $5.9 \pm 0.5^{\# \&}$ \\
\hline Glutathione reductase, $\mathrm{nM} / \mathrm{mg} \cdot \mathrm{min}$ & $18.9 \pm 0.4$ & $16.0 \pm 0.9^{*}$ & $20.0 \pm 1.2^{\#}$ & $15.1 \pm 0.6^{\star \wedge}$ & $23.6 \pm 3.2^{\# \&}$ \\
\hline
\end{tabular}




\section{RESULTS AND DISCUSSION}

The effects of UC-MMSCs and melatonin administration on the behavioral response and oxidative stress in the brain of aged mice with a cuprizone diet.

It was found that the values of most of the studied behavior parameters in mice with a cuprizone diet are lower than in the intact group of animals (Table 2). After melatonin injections, the number of crossed squares and boluses in experimental mice increases to the values of intact animals.

After UC-MMSCs transplantation, the number of rearings is significantly higher than in the control group, and the latency time on the rotarod test does not differ from the values of the intact group. Injections of UC-MMSCs in combination with melatonin lead to an increase in the number of crossed squares, rearings, grooming and the rotarod latency time compared to the control group. In this case, the number of squares and the latency time on the rotarod exceed those in the group with the administration of cells alone, and the number of grooming and the latency time on the rotarod exceed those in the group with the administration of melatonin alone. That is, in mice with a cuprizone diet, UC-MMSCs transplantation leads to an increase in the exploratory activity and muscle tone, and the muscle tone index reaches the values of the intact group. After the transplantation of cells in combination with melatonin, the horizontal motor and exploratory activity did not differ from those of intact animals, and some parameters of emotional activity and muscle tone even exceeded them.

It was found that in the brain of aged mice with a cuprizone diet, the content of MDA increases and the activity of all antioxidant enzymes decreases in comparison with the intact group of animals (Table 2). After the administration of melatonin in such mice, the MDA content and the activity of glutathione peroxidase and glutathione reductase in the brain did not differ from the values detected in intact mice.

After UC-MMSCs transplantation, the values of all the studied parameters remain unchanged, while the administration of cells in combination with melatonin leads to a significant decrease in the MDA content and an increase in the activity of GP and GR in comparison with the control groups and with the transplantation of cells only. At the same time, the activity of GP and GR does not differ from that detected in mice with injections of melatonin alone.

Thus, the transplantation of UC-MMSCs into aged mice with a cuprizone diet has a positive effect on some parameters of behavioral response. Melatonin injections after UC-MMSCs transplantation not only enhance the positive effect of cells on a some of behavioral reactions, contributing to their normalization (number of rearings), but also contribute to the appearance of manifestation after injection of cells alone (number of squares). A significant increase in muscle tone after the combined administration of UC-MMSCs and melatonin requires further study with the aim of a possible adjustment of melatonin doses. An increase in the antioxidant protection of the brain of aged mice with a cuprizone diet was shown after administration of UC-MMSCs in combination with melatonin.

The effects of UC-MMSCs and rhFGF-2 administration on the behavioral response and oxidative stress in the brain of aged mice with a cuprizone diet.

We found that in mice that took cuprizone, the values of most of the studied behavioral parameters decreased and remained so after injections of rhFGF-2 (Table 3). In the group of mice transplanted with UC-MMSCs, the number of rearings and latency time on the rotarod are significantly higher than in the control group. The administration of UC-MMSCs and rhFGF-2 leads to a significant increase in the number of squares compared to mice not only in the control group, but also those injected with cells or growth factor alone. In this experimental group, the number of rearings is also greater than in mice with a cuprizone diet only. Thus, the transplantation of UC-MMSCs in combination with rhFGF-2 led to an increase in the decreased horizontal activity, but not to the level of intact animals.

It was found that in mice taking cuprizone, the activity of most antioxidant enzymes in the brain decreases against the background of an

\begin{tabular}{|c|c|c|c|c|c|}
\hline \multirow[b]{2}{*}{ INDICATOR } & \multicolumn{5}{|c|}{ EXPERIMENTAL GROUPS } \\
\hline & $\begin{array}{l}\text { INTACT } \\
(\mathrm{n}=10)\end{array}$ & $\begin{array}{c}\text { CUPRIZONE + } \\
\text { SALINE } \\
\text { (CONTROL) } \\
(\mathbf{n}=\mathbf{1 0})\end{array}$ & $\begin{array}{c}\text { CUPRIZONE + } \\
\text { rhFGF-2 } \\
(n=10)\end{array}$ & $\begin{array}{c}\text { CUPRIZONE + } \\
\text { UC-MMSCs } \\
(n=10)\end{array}$ & $\begin{array}{l}\text { CUPRIZONE + } \\
\text { UC-MMSCS+ } \\
\text { RHFGF-2 } \\
(n=10)\end{array}$ \\
\hline \multicolumn{6}{|l|}{ Behavioral testing } \\
\hline Number of crossings & $43.9 \pm 5.1$ & $10.2 \pm 2.1$ * & $12.5 \pm 1.2^{*}$ & $14.1 \pm 1.8$ * & $26.0 \pm 2.2^{* \# \& \wedge}$ \\
\hline Number of rearings & $1.2 \pm 0.2$ & $0.3 \pm 0.1$ * & $0.4 \pm 0.1^{\star}$ & $0.6 \pm 0.1^{\star \#}$ & $0.7 \pm 0.1 * \# \wedge$ \\
\hline Number of boluses & $1.4 \pm 0.2$ & $0.2 \pm 0.05$ * & $0.3 \pm 0.1^{\star}$ & $0.2 \pm 0.05$ * & $0.2 \pm 0.06$ * \\
\hline Number of explored holes & $2.8 \pm 0.4$ & $0.7 \pm 0.2$ * & $0.6 \pm 0.1^{*}$ & $0.7 \pm 0.2$ * & $0.6 \pm 0.1$ * \\
\hline Number of grooming & $0.5 \pm 0.2$ & $0.4 \pm 0.1$ & $0.5 \pm 0.1$ & $0.6 \pm 0.2$ & $0.5 \pm 0.1$ \\
\hline Rotarod, sec & $79.2 \pm 4.6$ & $62.2 \pm 3.2$ * & $61.1 \pm 2.8^{*}$ & $81.0 \pm 4.1^{\# \Lambda}$ & $78.1 \pm 3.1^{\# \wedge}$ \\
\hline \multicolumn{6}{|l|}{ Markers of oxidative stress in the brain } \\
\hline Malondialdehyde, nM/mg & $3.8 \pm 0.1$ & $4.5 \pm 0.2$ * & $5.1 \pm 0.3$ * & $4.2 \pm 0.1 * \wedge$ & $3.7 \pm 0.2 \# \& \wedge$ \\
\hline Superoxide dismutase, U/mg.min & $14.1 \pm 1.2$ & $10.7 \pm 1.1$ * & $10.0 \pm 1.2$ * & $9.3 \pm 1.3$ * & $16.0 \pm 1.9 \# \& \wedge$ \\
\hline Catalase, $\mu \mathrm{M} / \mathrm{mg} \cdot \min$ & $2.2 \pm 0.2$ & $1.5 \pm 0.2$ * & $1.3 \pm 0.1$ * & $1.6 \pm 0.2$ * & $1.5 \pm 0.1^{*}$. \\
\hline Glutathione peroxidase, $\mathrm{nM} / \mathrm{mg} \cdot \mathrm{min}$ & $5.2 \pm 0.4$ & $4.8 \pm 0.3$ & $5.0 \pm 0.3$ & $4.5 \pm 0.5$ & $5.6 \pm 0.4$ \\
\hline Glutathione reductase, $\mathrm{nM} / \mathrm{mg} \cdot \mathrm{min}$ & $14.7 \pm 0.4$ & $13.5 \pm 0.3$ * & $12.9 \pm 0.2$ * & $14.1 \pm 0.3^{*}$ & $13.2 \pm 0.3^{*}$ \\
\hline
\end{tabular}


increase in the MDA content (Table 3). In the groups of mice that were injected with rhFGF-2 or UC-MMSCs only, the values of all studied parameters remained unchanged. Whereas, the administration of cells and rhFGF-2 leads to a significant decrease in the MDA content and an increase in SOD activity in the brain. At the same time, the values of the parameter do not differ from other experimental groups and correspond to those of the intact group of mice.

Thus, the transplantation of UC-MMSCs has a positive effect on the behavioral parameters of aged mice, altered by the cuprizone diet. Injections of rhFGF-2 after cell transplantation lead to an increase in horizontal locomotor activity, and also retain the effect of cell administration on vertical locomotor activity and muscle tone in mice. In addition, in aged mice with a cuprizone diet, after administration of UC-MMSCs and rhFGF-2, positive changes in the balance of factors of oxidative stress and antioxidant protection of the brain are observed.

The effects of UC-MMSCs and melatonin in aged mice with demyelinating diseases.

Positive changes in the behavior of mice with a cuprizone diet after the transplantation of UC-MMSCs can most likely be associated with their anti-inflammatory properties, in particular, the synthesis of IL-10, a decrease in the manifestation of active gliosis in the brain [25, 31]. According to our data, in mice with a cuprizone diet, the number of active macrophages in the brain decreases under the influence of cytokines with an anti-inflammatory effect [28].

In this experiment, we showed that the effect of UC-MMSCs on the behavior of aged mice with a cuprizone model of demyelination is enhanced in the case of their combination with melatonin, and, in addition, there are positive changes in those parameters of behavior that were $a b-$ sent after the transplantation of the cells only. Considering the unidirectional changes in the studied parameters in the groups with the administration of melatonin only, as well as its combination with UC-MMSCs, it can be assumed that the positive effects of such a combination are largely associated with melatonin.

At the same time, melatonin is able to enhance neuro- and myelogenesis, which is due to its ability to penetrate the blood-brain barrier and change the synthesis of brain-derived neurotrophic factor (BDNF), viability, proliferation and differentiation of neural stem cells (NSCs), as well as the content of myelin basic protein in oligodendrocytes [2, 32, 33]. We have previously shown an increase in neurogenesis in the brain of aged mice on a cuprizone diet that received melatonin injections [14]. According to the literary data, antioxidant and anti-inflammatory properties of melatonin are also important in demyelinating CNS pathology $[13,16]$. The results of our experimental studies made it possible to establish the activation of antioxidant enzymes (glutathione peroxidase and glutathione reductase) in the brain of aged mice that received injections of both melatonin alone and its combination with UC-MMSCs. We have previously shown a combination, on the one hand, of positive changes in behavior, a decrease in the number of altered neurons in the central nervous system, and, on the other hand, a decrease in the number of active macrophages and T-lymphocytes in the brain of aged mice treated with cuprizone and melatonin injections [14].

The effect of melatonin on the biological properties of transplanted MMSCs is known. Thus, it has been shown that melatonin protects MMSCs from apoptosis, the death of which in the case of alone transplantation reaches $80-90 \%$ during the first 72 hours [34]. Under the influence of melatonin, the production of such pro-inflammatory factors as TNF-a and IL-6 decreases in MMSCs of various origins [12, 34]. This hormone regulates the expression of the NADPH oxidase gene in MMSCs, which generates reactive oxygen species, and also activates the expression of genes for antioxidant enzymes in these cells [11,32]. Therefore, it can be assumed that the above properties of melatonin are important for enhancing the therapeutic effect of UC-MMSC transplanted into aged mice with demyelinating pathology.

\section{Effects of UC-MMSCs and rhFGF-2 in aged mice with demyelinating} diseases.

It was found that FGF-2 is a multifunctional growth factor with a pronounced effect on angiogenesis, proliferation of NSCs and oligodendrocyte precursors in the brain [35]. We have previously found an increase in the number of unchanged neurons in the brain, as well as in the motor activity of adult mice treated with cuprizone and rhFGF-2 injections [21].

In this study, we showed a positive effect of UC-MMSCs injections in combination with rhFGF-2 on the locomotor activity of aged mice with a cuprizone model of demyelination. One of the possible ways this combination influences the behavior of mice is the change of the balance of oxidative stress and antioxidant defense factors in the brain. Indeed, we have established a decrease in MDA content and an increase in SOD activity in the brain of aged mice with a cuprizone diet. These results are consistent with the data of other authors who showed the ability of FGF-2 to exhibit an antioxidant effect in the pathology of CNS [22]. In addition, the possibility of manifestation of the anti-inflammatory effect of rhFGF-2 in the brain of aged mice on a cuprizone diet is not excluded. Other authors and we have found that after FGF-2 injections, the number of microglial cells and active macrophages in the brain of mice with demyelinating diseases decreases [21, 35].

Noteworthy is the fact that the FGF-2 production by MMSCs increases under the influence of melatonin, which is accompanied by an increase in angiogenesis and neurogenesis in the brain of animals with CNS disorders [23]. When comparing the effects of combined administration of UC-MMSCs with melatonin or rhFGF-2 to aged mice on a cuprizone diet, both their common and specific features were found. In particular, it was shown that both combinations of UC-MMSCs with the studied biologically active factors are able to improve the therapeutic effect of the transplanted cells in these mice. However, the positive effect of the combination of UC-MMSCs and melatonin on the behavior and antioxidant protection of the brain of aged mice on a cuprizone diet was found to be more significant than the combination of cells and rhFGF-2. This can be confirmed by the following results of our experiments. While in mice the transplantation of UC-MMSCs in combination with rhFGF-2 led to a significant increase (but did not normalize) horizontal locomotor activity, in the combination of cells with melatonin, its restoration to normal values was observed, as well as exploratory activity was restored. Although the administration of UC-MMSCs in combination with both melatonin and rhFGF-2 was accompanied by a decrease in the content of MDA in the brain and an increase in the activity of antioxidant enzymes, in the case of a combination of cells with melatonin, an increase in the activity of enzymes was observed more often than with rhFGF-2 (2 out of 4 studied enzymes, and 1 out of 3 enzymes, respectively). It should be noted that the same focus of positive changes in some parameters of behavior and oxidative stress in the groups of experimental mice treated with UC-MMSCs both with melatonin and rhFGF-2 gives grounds for assuming that the latter is involved in the realization of such effects of melatonin.

The obtained results can be useful in the development of approaches that increase the effectiveness of cell therapy for demyelinating diseases in an aged humans. 


\section{CONCLUSION}

Human UC-MMSCs transplantation has a positive effect on the exploratory activity and muscle tone of aged mice with a cuprizone model of demyelination.

Melatonin injections after UC-MMSCs transplantation enhance the effect of cells on the behavioral responses of aged mice with a cuprizone diet and, moreover, lead to the positive changes in the parameters of motor and emotional activity.

The injections of rhFGF-2 after the transplantation of UC-MMSCs lead to an increase in horizontal locomotor activity in aged mice with a cuprizone model of demyelination.

In mice with a cuprizone diet, which were injected with UC-MMSCs in combination with melatonin or rhFGF-2, the malondialdehyde content in the brain decreases and the activity of antioxidant enzymes increases.

The positive effect of the administration of UC-MMSCs in combination with melatonin on the behavior and antioxidant protection of the brain of aged mice with a cuprizone model of demyelination is higher than that after the injection of cells and rhFGF-2.

Funding: the study was carried out according to the project No. 0119 U000087 with the financial support

of the National Academy of Medical Sciences of Ukraine.

\section{REFERENCES:}

1. Vaughn GB, Jakimovski D, Weinstock-Guttman B. Epidemiology and treatment of multiple sclerosis in elderly populations. Nature Reviews. Neurology. 2019; 15:329-342. DOI: 10.1038/s41582-019-0183-3.

2. Sarlak G, Jenwitheesuk A, Chetsawang B, Govitrapog P. Effects of melatonin on nervous system aging: neurogenesis and neurodegeneration. J Pharmacol Sci. 2013; 123:9-24. PMID: 23985544.

3. Sarcar P, Rice CM, Scolding NJ. Cell therapy for multiple sclerosis. CNS Drugs. 2017; 31:453-469. DOI: 10.1007/s40263-017-0429-9.

4. Genc B, Bozan HR, Genc S, Genc K. Stem cell therapy for multiple sclerosis. Adv Exp Med Biol. 2019; 1084:145-174. D0l: 10.1007/5584_2018_247.

5. Can A, Celikkan FT, Cinar O. Umbilical cord mesenchymal stromal cell transplantation: a systemic analysis of clinical trials. Cytotherapy. 2017; 19(12):1351-1382. DOI:10.1016/j.cyt.2017.08.004.

6. ElOmar R, Beroud J, Stoltz JF, Menu P, Velot E, Decot V. Umbilical cord mesenchymal stem cells-based therapies? Tissue Eng Part B Rev. 2014; 20(5):523-544. DOI: 10.1089/ten.TEB.2013.0664.

7. Putra A, Ridwan BR, Putridewi Al, Kustiyah AR, Wirastuti K, Sadyah NACh, et al. The role of TNF-alpha induced MSCs on suppressive inflammation by increasing TGF-beta and IL-10. Open Access Maced J Med Sci. 2018; 6(10):1779-1783.

8. Shen J, Tsai Y-T, Di Marco NM, Lang MA, Sun X, Tang L. Transplantation of mesenchymal stem cells from young donors delays aging in mice. Scientific reports. 2011; 1:67. DOI: 10.1038/srep00067.

9. Fabian C, Naaldijk Y, Leovsky Ch, Johnson AA, Rudolph I, Jaeger C, et al. Distribution pattern following systemic mesenchymal stem cell injection depends on the age of the recipient and neuronal health. Stem Cell Res Ther. 2017; 8(85). DOI: 10.1186/s13287-017-0533-2.

10. Labunets I, Utko N, Toporova O, Panteleymonova T, Rodnichenko A, Butenko G. The effects of human umbilical cord multipotent mesenchymal stromal cells on the behaviour and oxidative stress in the brain of mice of different ages with a cuprizone-induced model of demyelination. Cell Organ Transpl. 2020; 8(1):38-42. DOl: 10.22494/cot.v8i1.106

11. Hu Ch, Li L. Melatonin plays critical role in mesenchymal stem cell-based regenerative medicine in vitro and in vivo. Stem Cell Res Ther. 2019. 10. DOI: 10.1186/ s13287-018-1114-8.

12. Zhang S, Chen S, Li Y, Liu Y. Melatonin as a promising agent of regulatory stem cell biology and its application in disease therapy. Pharmacol Res. 2017; 117:252260. DOI: $10.1016 /$ jphrs.2016.12.035

13. Anderson G, Rodriguez M. Multiple sclerosis:the role of melatonin and N-acethylserotonin. Multiple sclerosis and related disorders. 2015; 4:112-123. D0I: 10.1016/j.msard.2014.12.001.

14. Labunets IF, Rodnichenko AE. Effekty melatonina u molodykh i stareyushchikh myshey s toksicheskoy kuprizonovoy model'yu demielinizatsii [Effects of melatonin in young and aging mice with toxic cuprizone demyelination model]. Uspekhi gerontol - Adv geront. 2019; 32(3):338-346. PMID: 31512419. [In Russian]

15. Kashani IR, RaJabi Z, Akbari M, Hassanzadeh Gh, Mohseni A, Eramsadati MK, et al. Protective effects of melatonin against mitochondrial injury in a mouse model of multiple sclerosis. Exp Brain Res. 2014; 232(9):2835-2846. D0I: 10.1007/s00221-014-3946-5.

16. Wurtman R. Multiple sclerosis, melatonin and neurobehavioral diseases. Front Endocr 2017; 8. D0I: 10.3389/fendo.2017.00280.

17. Huang $Y$, Dreyfusm ChF. The role of growth factors et a therapeutic approach to demyelinating disease. Exp Neurol. 2016; 283:531-540. D0I: 10.1016/j. expneurol.2016.02.023.

18. Coutu DL, Galipeau J. Roles of FGF signaling in stem cell self-renewal, senescence and aging. Aging. 2011; 31(10):920-933. Available from: http: www.impactaging . com

19. Noda M, Takii K, Parajuli B, Kawanokuchi J, Sonobe $Y$, Takeuchi $H$, et al. FGF-2 released from degenerating neurons exerts microglial-induced neuroprotection via FGFR3-ERK signaling pathway. J neuroinflam. 2014; 11:76. DOI: 10.1186/1742-2094-11-76.

20. Rottlaender A, Villwock $H$, Addicks $K$, Kuerten $S$. Neuroprotective role of fibroblast growth factor-2 in experimental autoimmune encephalomyelitis. Immumology. 2011; 133:370-378. DOI: 10.1111/j.1365-2567.2011.03450.x.

21. Labunets I, Rodnichenko A, Utko N, Panteleimonova T, Pokholenko Ya, Litoshenko Z, et al. Effects of interleukin-10 and fibroblasts growth factor 2 in mice with toxic cuprizone model of demyelination. Cell Organ Transpl. 2019; 7(1):25-31. DOI: 10.22494/cot.v7i1.93.

22. Wang L, Li Xi-Xi, Chen Xi, Qin X-Y, Kardami E, Cheng Y. Anti-depresant-like effects of low- and high molecular weight FGF-2 on hronic unpredictable mild stress. Front Mol Neurosci. 2018; 11:377. DOI: 10.3389/fnmol.2018.00377. 
23. Tang V, Cai B, Yuan F, He X, Lin X, Wang J, et al. Melatonin pretreatment improves the survival and function of transplanted mesenchymal stem cells after focal cerebral ischemia. Cell Transplantation. 2014; 23(10):1279-1291. D0l: 10.3727/096368913X667510.

24. Praet J, Guglielmetti C, Berneman Z, Van der Linden A, Ponsaerts $P$. Cellular and molecular neuropathology of the cuprizone mouse model: Clinical relevance for multiple sclerosis. J Neubiorev. 2014; 47:485-505. Doi.org/10.10161/j.neubiorev.2014.10.004.

25. Tsymbaliuk VI, Velychko OM, Pichkur OL, Verbovska SA, Shuvalova NS, Toporova OK, et al. Effects of Warton's jelly humans mesenchymal stem cells transfected with plasmid containing il-10 gene to the behavioral response in rats with experimental allergic encephalomyelitis. Cell Organ Tranpl. 2015; 3(2):139-143. DOI: 10.22494/COT.V3I2.14.

26. Maslova 00, Shuvalova NS, Sukhorada OM, Zhukova SM, Deryabina OG, Makarenko MV, et al. Heterogeneity of Umbilical Cords as a Source for Mesenchymal Stem Cells. Dataset Paper. 2013; 2013. Available from: https://doi.org/10.7167/2013/370103.

27. Seglen PO. Preparation of isolated rat liver cells. Meth. Cell. Biol. 1976; 13:29-83.

28. Labunets IF, Rodnichenko AE, Melnyk NO, Rymar SE, Utko NA, Gavrulyk-Skyba GO, et al. Neuroprotective effect of the recombinant human leukemia inhibitory factor in mice with an experimental cuprizone model of multiple sclerosis: possible mechanisms. Biopolym Cell. 2018; 34(5):350-360. D0I: 10.7124/bc000989.

29. Nessler J., Benardais K, Gudi V, Hoffman A, Tejedor LS, JanBen S, et al. Effects of murine and human bone marrow-derived mesenchymal stem cells on cuprizone induced demyelination. PloS ONE. 2013; 8(7):69795-8. DOl: 10.1371/journal.pone 0069795.

30. Amikishieva AV. Povedencheskoe fenotipirovanie: sovremennye metody i oborudovanie [Behavioral phenotyping: modern methods and equipment]. VOGiS Bulletin 2009; 13(3):529-542. [In Russian]

31. Mukai T, Mon Y, Shimazu T, Takahashi A, Tsunoda H, Yamaquchi S, et al. Intravenous injection of umbilical cord-derived mesenchymal stromal cells attrnuates reactive gliosis and hypomyelination in neonatal intraventricular hemorrhage model. Neuroscience. 2017; 355:175-187. DOI: 10.1016/j.neuroscience.2017.05.006.

32. Kim W, Hahn KR, Jung H, Kwon HJ, Nam SM, Kim JW, et al. Melatonin ameliorates cuprizone-induced reduction of hippocampal neurogenesis, brain-derived neurotrophic factor, and phosphorylation cyclic AMP response element-binding protein in the mouse dentate gyrus. Brain Behav. 2019; 9. DOI: 10.1002/brb3.1388.

33. Li X, Zheng H, Ho J, Ho J, Chan MT, Wu WKK. Protective roles of melatonin in central nervous system disease by regulation of neural stem cells. Cell proliferation. 2016; 50. DOI: 10.1111/cpr.12323.

34. Luchetti F, Canonico B, Bartolini D, Arcangeletti M, Ciffolilli S, Murdolo G, et al. Melatonin regulates mesenchymal stem cell differentiation: a review. J Pineal Res. 2014; 56:382-397. DOI: 10.1111/jpi.12133.

35. Woodbury ME, Ikezu T. Fibroblast growth factor-2 signaling in neurogenesis and neurodegeneration. J Neuroimmune Pharmacol. 2014; 9(2):92-101. DOI: 10.1007/ s11481-013-9501-5.

\begin{tabular}{|c|c|}
\hline TRTICL ON THE SITE \\
\hline
\end{tabular}

The authors declared no potential conflicts of interest with respect to the research, authorship, and/or publication of this article. 


\title{
Ефекти комбінованого введення мультипотентних мезенхімальних стромальних клітин пуповини людини та мелатоніну або фактора росту фібробластів-2 старіючим мишам з токсичною купризоновою моделлю демієлінізації
}

\author{
Лабунець І. Ф. ${ }^{1}$, Утко Н. О. ${ }^{1}$, Топорова О. К. ${ }^{1,2}$, Похоленко Я. О. ${ }^{1,2}$, Пантелеймонова Т. М. ${ }^{1}$, \\ Літошенко 3. Л. ${ }^{1}$, Бутенко Г. М. ${ }^{1}$ \\ ${ }^{1}$ ДУ «Інститут генетичної та регенеративної медицини Національної академії медичних наук України», Київ, Україна \\ ${ }^{2}$ Інститут молекулярної біології та генетики Національної академії наук України, Київ, Україна
}

\section{PEЗЮME}

Ефрект трансплантації мультипотентних мезенхімальних стромальних клітин пуповини (ММСК-П) людини при демієлінізуючій патології залежить від віку реципієнта і може змінюватися під впливом гормонів або ростових фракторів.

META - дослідити вплив екзогенного мелатоніну і рекомбінантного фактора росту фрібробластів-2 людини (rhFGF-2) на ефекти ММСК-П, трансплантованих старіючим мишам з експериментальною моделлю розсіяного склерозу.

МАTEPIAЛИ ТА МЕТОДИ. Миші лінії 129/Sv у віці 15-17 міс отримували з їжею нейротоксин купризон протягом 3 тижнів. 3 10-ї доби купризонової дієти вводили МMCK-П (500 тис. клітин) 1 раз, з 11-ї доби - мелатонін о 18.00 або rhFGF-2. Досліджували поведінкові реакції в тесті «відкрите поле» $i$ «ротарод-тест». В головному мозку визначали активність супероксид дисмутази, каталази, глютатіон пероксидази, глютатіон редуктази та рівень малонового діальдегіду (МДА).

РЕЗУЛЬТАТИ. Прийом купрізону знижує показники поведінкових реакцій мишей у порівнянні з інтактною групою. Трансплантація ММСК-П підвищує число стійок і м'язовий тонус. Ін'єкції мелатоніну посилюють вплив клітин на зазначені поведінкові показники, а також збільшують рухову і емоційну активність тварин. Iн'єкції rhFGF-2 зберігають ефект клітин на показники поведінки і підвищують рухову активність мишей. Після введення МMCK-П з мелатоніном або rhFGF-2 в головному мозку знижується вміст МДА $і$ зростає активність антиоксидантних фрерментів, причому більш виражено під впливом мелатоніну.

Висновки. Екзогенний мелатонін і rhFGF-2 покращують есректи трансплантованих МMCK-П на поведінку і антиоксидантний захист головного мозку старіючих мишей з купризоновою дієтою. При цьому позитивний вплив комбінації клітин з мелатоніном більш виражений.

ключовI СловА: мультипотентні мезенхімальні стромальні клітини пуповини; мелатонін; rhFGF-2; купризон; демієлінізація; поведінкові реакції; оксидативний стрес 